\title{
Ecofeminist Echoes in New Materialism?
}

\author{
Marie-Anne Casselot
}

Why should we think ecofeminism and new materialism together? I argue in this paper that bringing them together is a fruitful project because ecofeminism can offer illuminating insights to new materialism especially when it comes to analyzing oppression and the effects of oppressive structures on humans, 'natural others' and more-than-human elements. New materialism would benefit from a close rereading of ecofeminist theory and history, and by the same movement it could extend ecofeminist insights beyond a closed worldview of the natural world by infusing its dynamic new theorizations of the fluidity and the indeterminacy of matter. The political and ethical strength of ecofeminism could be enhanced by new materialist ontological claims because it makes clear the connection between corporeality and environment, while avoiding positing a gendered special connection to nature. How can we achieve such an ambitious goal?

First, it is relevant to ask whether there are some ecofeminist echoes in feminist new materialist thought This "return to matter" is a relatively new trend and one can ask what its place is in feminist genealogies of academe. There is little mention of ecofeminism in new materialist literature: for example, Elizabeth Grosz clearly disassociates herself from ecofeminism and Rosi Braidotti, even if she co-authored the book Women, the Environment and Sustainable Development in 1994, does not seem interested in this movement anymore. Neither of the two main new materialist anthologies (Coole \& Frost : 2010, Dolphijn \& van der Tuin : 2012) discuss "ecofeminism" or "environmental feminism." In the introduction of Material Feminisms, Stacy Alaimo and Susan Hekman acknowledge the legacy of ecofeminism, but in the collected essays there are none (except for Alaimo's piece itself) that explicitly address ecofeminism as a political movement and as a theoretical subfield of feminist theory. ${ }^{1}$ They discuss how "thinking through the co-constitutive

\footnotetext{
1 "Environmental feminists have long insisted that feminism needs to take the materiality of the more-than-human world seriously. Mainstream feminist theory, however, has, more often then not, relegated ecofeminist to the backwoods, fearing that any alliance between feminism and environnmentalism could only be founded upon a naïve, romantic account of reality. [...] predominant feminist theories [...] have pursued a 'flight from nature' relentlessly disentangling 'woman' from the supposed ground of essentialism, reductionism and stasis. The problem with this approach is that the more feminist theories
} 
materiality of human corporeality and nonhuman natures offers possibilities for transforming environmentalism itself" (Alaimo \& Hekman 6). However, their collected essays rarely mention gender, which is surprising for an explicitly feminist anthology. Regardless of ecofeminism's absence within main new materialist texts, I am convinced that we can draw commonalities between them by exposing where ecofeminist ideas linger in new materialism.

Ecofeminism has been disregarded in feminist theory partly because the reference to nature had to be avoided in dominant linguistic or constructivist turn of the 1990s. Painted as mostly essentialist, ecofeminism suffered from this reductive gesture and its richness has not been acknowledged to its full extent. Now that we live the 'material turn', we can further ask: was it even easier, because of the previous constructivist or linguistic dismissal of ecofeminism, to overlook ecofeminism in this gesture of going back to matter?

I contend that feminist materialist thought was prefigured in some ecofeminist thinking, especially given ecofeminism's aim to bring ecological and feminist thinking beyond the nature-culture divide and its goal to ground an ethical movement in a 'new metaphysics' of nature. Mainly as ecological and feminist advocacy, ecofeminism is of interest for academics because it connects questions of gender to the environment. New materialism stands out as a 'return' to matter across the humanities, but also within natural sciences. Although new materialism does have strong ties to feminist theory, its 'transversality' goes even beyond the scope of feminism, as it questions science, biology, geography and physics on ontological considerations of nature, matter and time (Dolphijn \& van der Tuin : 2010). I do not pretend to offer an exhaustive account of either ecofeminism or new materialism here. Because of their respective breadth it is perhaps clumsy to talk of either of them in the singular. Of course, there is neither "an" ecofeminism nor " $a$ " new materialism: both include a wide range of positions, claims and theorists that are sometimes at odds with each other. Hence I use the singular only for clarity's sake. Indeed I will at times distinguish between "political ecofeminism" and "cultural ecofeminism," and "new materialism" will be an umbrella term including mostly "materialist feminism" as well as a few other perspectives including posthumanism.

In this paper, I want to disclose new paths of investigation in order to reactualize ecofeminism's political potential for a feminist investigation

distance themselves from 'nature', the more that very 'nature' is implicitly or explicitly reconfirmed as the treacherous quicksand of misogyny. Clearly, feminists who are also environmentalists, cannot be content with theories that replicate the very nature/culture dualism that has been so injurious [...] we must reconceptualize nature itself." (Alaimo \& Hekman 4-5). 
of nature and connect it to the rich and dynamic work done in new materialism. I aim to explore the possible connections and differences between these subfields. Specifically, they share an interest for dualism, embodiment, the nonhuman and the more-than-human, and their respective political and ethical goals, and finally their interdisciplinarity. But they differ on technology and posthumanism, on agency, on essentialism, and new materialism's positive methodology.

\section{Ecofeminist Echoes}

Can we draw some commonalities between ecofeminism and new materialism at all? It is possible to assess similarities between these subfields without reducing one to the other. I identify various shared interests : a common concern for overthrowing dualism, an interest in the connection between embodiment and the environment, a critical concern for animals and natural elements, and our interactions with them. Furthermore, they are both political and interdisciplinary subfields. Also, it is worth noting that their respective interdisciplinarity generated constructive debates among feminist theorists, but they are beyond the scope of this paper. ${ }^{2}$ I believe we can push further their similarities in order to strengthen new feminist thinking.

\section{a) What are we talking about: ecofeminism and new materialism}

As for what ecofeminism and new materialism are, I will define them as the following: ecofeminism is a subfield intersecting environmental theory and feminist theory. It is concerned by the oppression of women and the oppression of nature whereas new materialism is concerned with materiality in the broadest sense, as we are already immersed in a physical world, surrounded and constituted by matter. On the one hand, ecofeminism links the oppression of women, animals and nature as symbolically, structurally and politically similar because "embodiment and nature have been exploited as a rich source for images of otherness." (Twine 2010). Importantly, ecofeminism has been rooted in ecological and feminist activism since the 1970s up to the mid-1990s. Famously demonstrated by Carolyn Merchant, ecofeminism is critical of the "Woman-Nature metaphor" which portrays both women and "Nature" as irrational, sub-human, passive and susceptible to manipulation by an "active masculine" will (Merchant 1980; D’Eaubonne 1974; Plumwood 1993). There seems to be a double effect of naturalizing women in order to

${ }^{2}$ See the debate between Sara Ahmed (2008), Noela Davis (2009) and Iris van der Tuin (2008). 
exclude them from certain domains of human life and a "feminization" of the environment in order to exploit it (Merchant 1980).

However, ecofeminism's political strength has been undermined by its essentialist trends valuing women's closeness to nature because of their reproductive capacities. Briefly, essentialism posits a common essence shared by all women, grounding identity in biology or a shared universal trait (Fuss 1989; Guillaumin 1992). Essentialism has been used as a reactionary tool to exclude populations on the basis of their naturalness, and to justify treating them as "less rational" beings. In the case of ecofeminism, some ecofeminists reclaimed femininity as a trait or a force potentially more respectful of nature because of its connection to life. In contrast, political ecofeminists refused to valorize a special essence connected to nature and rather identify where, in the sexual division of labor, women have been cast as the 'natural' caregiver because of their reproductive capacities. Indeed, political ecofeminism denies the reality of such a shared identity based on an intrinsic essence common to all women: identity is socially constructed by various elements such a cultural norms, ideology, class, race and gender. The tension within ecofeminism is real: the cultural ecofeminist's assertion of a feminine essence closer to nature is in opposition to the critique of this same essentialism as an exclusionary device oppressing women and nature alike, coming from patriarchy, capitalism and imperialism.

This tension can be explained by the fact that many trends coexist within ecofeminism, going from spiritual ecofeminism, Marxist-oriented ecofeminist analysis of work, cyborg ecofeminism, animal rights ecofeminism, and many more. ${ }^{3}$ Another hint that ecofeminism generates disagreement is the controversy about the label 'ecofeminist' itself: some use "ecofeminism" as a synonym of "political feminist ecology", while others add adjectives to specify their stance such as "social ecofeminism" or "cyborg ecofeminism" (Plumwood: 1993, Sturgeon: 1997). Also, others reject the term and favour "environmental feminism" or "ecological feminism" (Agarwal: 2001). A deep discomfort exists about ecofeminism

\footnotetext{
3 For instance, figures such as Starhawk or Mary Daly could represent a spiritual ecofeminist trend; the former reclaims pagan mythologies for a feminist spirituality and the latter criticizes patriarchal religions while advocating for a female-centered spirituality (Starhawk: 1989, Daly: 1978). Françoise d'Eaubonne, who supposedly 'coined' the word 'ecofeminism', pertained to radical feminism analyzing patriarchy and capitalism as the roots of the oppression of women and nature (1974). Maria Mies sees capitalism and economic growth in a Marxist ecofeminist lens, arguing that the destruction of ecosystems endangers not only humanity, but the very foundation of life itself (Mies and Shiva: 1993). Vandana Shiva looks at means of subsistence of Indian women, but also at the disastrous effects of water pollution, and argues for a reappropriation of the feminine principle as creator of diversity. Noël Sturgeon, argues for strategic essentialism in order to politically mobilize around identity without asserting it as a universal category for women (Sturgeon: 1997).
} 
because of its association with essentialism. Hence it is a fact that some strands of ecofeminism are irreducible and thus this project cannot pretend to bridge all ecofeminism with new materialism.

Also, ecofeminism has been concerned with the oppression of animals; such as it links their inferior status to their "naturalness" and their lack of "agency" and "rationality" (Adams 1990, Gruen 2011). Ecofeminist insights into animal issues allowed opening a theoretical space for understanding agency outside the narrow anthropocentric understanding, but it also questioned our food habits and their intrinsic dependency on a wide-scale oppressive system. Finally, ecofeminism distinguishes itself from new materialism by having been, and remaining, a political movement uniting feminist, environmentalist and ecologist activism. For example, the ecofeminist movement reached its peak with its institutionalisation at the United Nations when "women and development" legislations were adopted throughout the 1990s.

On the other hand, new materialism, as a more recent field of theoretical inquiry, is grounded in social sciences as well as in natural sciences. New materialism brings together thinkers and philosophers such as Rosi Braidotti, Elizabeth Grosz, Karen Barad, Manuel DeLanda, Claire Colebrook, amongst many other. It is a theoretical stance that wants to recognize that "our existence depends [...] on myriad micro-organisms and diverse higher species, on our own hazily understood bodily and cellular reactions and on pitiless cosmic motions, the material artifacts and natural stuff that populate our environment, as well as socioeconomic structures that produce and reproduce the conditions of our everyday life" (Coole \& Frost 1). New materialism thus covers a wide range of philosophical topics, going from metaphysics to politics, via social structures and technologies.

New materialism is new because it is a recent theoretical shift in academia occurring after the "exhaustion of once popular materialist approaches, [...]" and "as an effect of the dominance of analytical and normative political theory and radical constructivism of social sciences" (Coole \& Frost 3). New materialist literature criticizes how the "language turn' blinded theory to the physical aspect of our bodies, their interactions with other beings within nature and with the material world. Many new materialist theorists explored to great length how this concealment of matter happened during the 1980s and the 1990s; instead of deconstructing the nature-culture dichotomy, the 'constructivists' reinforced the 'culture' over the 'nature' side (Braidotti, Nomadic Thought 2011, Dolphijn \& van der Tuin 2012). More importantly, new materialism is interested in changing our ontological concepts of nature, matter, agency and reality in order to radically rethink nature and our interactions with it. New materialism frames itself as a "return" to matter, or a "material turn" towards material reality, a theoretical field that goes beyond an 
anthropocentric view of the world (Grosz 2005, Braidotti, Nomadic Thought 2011, Dolphijn \& van der Tuin 2012). Hence, new materialism is a "new metaphysics" that wants, nothing less than to "traverse and rewrite thinking as a whole" (Dolphijn \& van der Tuin 2012).

\section{b) Anti-dualism as a common goal}

First, ecofeminism and new materialism both share the common goal of disrupting dualisms in other to posit a new understanding of nature. In many instances of ecofeminist literature, one can find the mention of dualism and their negative impacts epistemologically (Plumwood 1993), politically (Sturgeon 1997), ontologically (Merchant 1980) and finally socially and economically (Mies and Shiva 1993). In the famous anthology Reweaving the World, Irene Diamond and Gloria Orenstein introduce ecofeminism as a field which reweaves the biological and the cultural together ${ }^{4}$ by dismantling dualism. Ynestra King's famous piece in this anthology, Healing the Wounds, defines an ecofeminist project with new materialist echoes because it would be "a genuinely antidualistic, or dialectical, theory and practice" (King, in Diamond and Orenstein 116). King's ecofeminism would "develop an ideal of freedom that is neither antisocial nor antinatural ". (King, in Diamond and Orenstein 119). However, it is in the way that King creates a new ontology that her definition of ecofeminist ethics is uncannily close to a new materialist definition of nature:

From an ecofeminist perspective, we are part of nature, not inherently good or bad, free or unfree. There is no one natural order that represents freedom. We are potentially free in nature, but as human beings that freedom has to be intentionally created by our understanding of the natural world. For this reason we must develop a different understanding of the relationship between human and nonhuman nature, based on the stewardship of evolution. To do this we need a theory of history where the natural evolution of the planet and the social history of the species are not separated. We emerged from nonhuman nature, as the organic emerged from the inorganic. Here potentially we recover ontology

\footnotetext{
4 "Ecofeminist politics does not stop short at the phase of dismantling the androcentric and anthropocentric biases of Western civilization. Once the critique of such dualities as culture and nature, reason and emotion, human and animal has been posed, ecofeminism seeks to reweave new stories that acknowledge and value the biological and cultural diversity that sustains life. These new stories honor, rather than fear, women's biological particularity while simultaneously affirming women as subjects and makers of history. This understanding that biological particularity need not be antithetical to historical agency is crucial to the transformation of feminism." (Diamond \& Orenstein: xi).
} 
as the ground for ethics. (King in Diamond and Orenstein 120, emphasis mine)

King clearly ties together freedom with our understanding of the natural world, and she further acknowledges our embeddedness in nature because we evolve as a species in relation and interaction with nonhuman nature. She stresses that we ought to create a history where the natural anchors the social: this new ontology would constitute the basis on which to elaborate a new environmental ethics. King's ecofeminist goal prefigures some new materialist claims of the importance of rethinking ontology for a new understanding and interrelations with the material. King's emphasis on the need of a new ontology that would ground a different ethics hints at this "return to matter" that is constituted by a change in our attitude towards animals and nature.

Val Plumwood is perhaps the philosopher who extensively studied, in Feminism and the Mastery of Nature, the negative impacts of Western dualism. For Plumwood, there are five oppressive mechanisms of dualism (Plumwood, Feminism and the Mastery of Nature 48-55). First, backgrounding is the mechanism by which the dominant "minimize and deny" the contribution of the oppressed while relying on it whereas hyperseparation, or radical exclusion, is the assertion of an "absolute discontinuity" between the dominant and the oppressed (48-55). Then, incorporation means the strategy of defining the other in relation to the dominant standards, hence establishing a lack, or, on the contrary, the process of incorporating a quality only on the dominant's terms. Fourth, instrumentalization is the process by which the dominant consider the other as a mere resource to be exploited, devoid of agency or subjectivity. Finally, homogenization is the last mechanism where all the oppressed class is regarded as the same, without individuality or in-class differences (48-55).

Interestingly enough, in her introduction, Plumwood states that "[o]vercoming the dualistic dynamic requires recognition of both continuity and difference; this means acknowledging the other as neither alien to and discontinuous from self nor assimilated to or an extension of self." (Plumwood, Feminism and the Mastery of Nature 6) Again, Plumwood's affirmation of continuity and difference indicate a will to change our understanding of the 'natural subject', and more generally, what 'nature' entails. Understanding 'natural others' as "neither alien nor assimilated to us" requires changing our theoretical framework about the subject and expanding our notion of agency; Plumwood's ontology is implied in her ethical and political project as she wants to advocate for a shift in thinking humanity with nonhumanity. Indeed Plumwood thinks that it is the hegemonic construction of agency with the nature-culture dualism that led Western thinking to see nature as inert and passive. 
Among new materialist thinkers, anti-dualism is a starting point for reconceptualizing matter. Indeed, "Dualism comes to the fore as the structuring principle of the transcendental and humanist traditions that they want to shift in their work." (Dolphijn \& van der Tuin 156). As seen in the New Materialisms anthology, main new materialists thinkers such a Manuel DeLanda and Rosi Braidotti constituted "dual oppositions as their main target." 5 They constructed their theories in developing alternatives beyond these oppositions, analyzing the inherent paradoxes created by dualism. "New materialism constitutes a philosophy of difference or immanence by working through or 'traversing' the dualisms that form the backbone of modernist thought" (Dolphijn \& van der Tuin 86). Indeed, Braidotti articulates her nomadic thought as a "materialist approach to philosophy that rests on a monistic vision of matter in opposition to dichotomous and dualistic ways of thought" (Braidotti, Nomadic Thought 3 ). Her nomadic thought is "physical, material as well as speculative and ethereal": hence she seeks to construct a theory enabling a positive account of difference, a becoming-nomad overthrowing main oppositional dualisms (Braidotti, Nomadic Thought 3). In so doing, the collapse of dualisms will "undo the dualistic mode and redistribute the power relations" between the two sides of the dichotomy (Braidotti, Nomadic Thought 42).

While ecofeminism does preliminary work of deconstructing dualisms, new materialism on the other hand takes dualism almost like a notion of the past that needs to be left behind. However for both of them, dualisms and their discontents are an important part of their critical conceptualizations of the world.

\section{c) Embodiment: shared site of theorization}

Embodiment is an important common concern for ecofeminists and new materialists. On the spiritual and cultural ecofeminist side, female embodiment has been a source of revalorization of women's bodily experiences such as menstruations, lactation, childbearing, etc., in order to reclaim them as a feminine spiritual force (Starhawk 1989). Indeed female embodiment and women's reproductive power have been strongly associated with natural cycles, and it should be revalorized instead of

\footnotetext{
5 "In addition to this, they worked on similar dualisms: like Braidotti, DeLanda (1996: np) targets 'the distinction between the natural and the artificial, but also that between the living and the inert', and like DeLanda, Braidotti (2006: 110) does not conceptualise matter as opposed to signification, but designed an 'approach that starts with asserting the primacy of life as production, or zoe as generative power." (Dolphijn \& van der Tuin 2010 156).
} 
rejected. ${ }^{6}$ Also within early radical ecofeminism, Françoise d'Eaubonne showed the link between ecology and reproduction, saying that ecology entails thinking about natality and the relations between the sexes. ${ }^{7}$ For D'Eaubonne, as patriarchy controlled soil and farming lands, the next logical step was to control and exploit women's reproduction. These common overexploitation led to a double menace of overpopulation and ecological destruction. ${ }^{8}$ Moreover, there has been an ecofeminist concern for the sexist and racist impacts of reproductive technologies on women's bodies: eugenics and population control are patriarchal and imperialist tools for populating or un-populating the Earth (Mies \& Shiva 1993, Diamond \& Orenstein 1990). While these concerns denote some antitechnology stances within ecofeminism, they nevertheless show a political struggle for women's bodily self-determination.

Moreover, sexual difference is at the center of the sexual division of labor, as showed by many political ecofeminists and feminists and it ultimately leads to a gender differentiated economy. This will lead some ecofeminists, like Maria Mies and Vandana Shiva, to argue for a subsistence perspective praising women when they make their bodies cooperate with the earth in order to "let grow and to make grow," instead of owning the earth in a way disconnected from nature, capitalist and imperialist in fashion (Mies \& Shiva 1993). On the contrary, Bina Agarwal refuses to revive a subsistence perspective because it "could further entrench women in unremitting, undervalued labour." (Agarwal 2001) In that latter perspective, women's bodies are the means of production of agricultural labour while also being at the forefront of ecological disasters and pollution. Finally, it is safe to say that women's embodiment have been at the center of ecofeminist research, be it in its role within global reproduction, sexual division of labour or within ecofeminist spiritualities.

\footnotetext{
${ }^{6}$ Nancy Hartsock explains well the cultural ecofeminism's reasoning of revalorizing the feminine, albeit not in the context of ecofeminism or new materialism: "The female construction of self in relation to others leads in an opposite direction - toward opposition to dualisms of any sort, valuation of concrete, everyday life, sense of a variety of connectednesses and continuities both with other persons and with the natural world. If material life structures consciousness, women's relationally defined existence, bodily experience of boundary challenges, and activity of transforming both physical objects and human beings must be expected to result in a world view to which dichotomies are foreign" (Hartsock 298).

7 "L'écologie, cette science qui étudie les rapports des êtres vivants entre eux et leur milieu physique où ils évoluent, comprend par définition le rapport des sexes et la natalité qui s'ensuit." (d'Eaubonne 223).

8 “[La société patriarcale] s'étant emparé du sol, donc de la fertilité, et du ventre des femmes (fécondité), il était logique que la surexploitation de l'une et de l'autre aboutissent à ce double péril menaçant et parallèle: la surpopulation -excès des naissances- et la destruction de l'environnement -excès des produits-." (D'Eaubonne 221).
} 
On the new materialist front, embodiment is yet a mutual starting point. Coole and Frost state : "For new materialists, no adequate political theory can ignore the importance of bodies in situating empirical actors within a material environment of nature, other bodies, and socioeconomic structures" (Coole \& Frost 19). They also mention that the new materialist approach to embodiment is more phenomenological, in the sense that it "emphasizes the active, self-transformative, practical aspects of corporeality as it participates in relationships of power" (Coole \& Frost 20). Perhaps it is within materialist feminisms that embodiment is a primary topic of study, as we "need a way to talk about the materiality of the body as itself an active, sometimes recalcitrant, force" (Alaimo \& Hekman 4). Indeed, material feminism is more specifically interested in the corporeality of the body, and in how gender and other embodied differences such as ability and race, structure our experience of the environment.

For example, Stacy Alaimo interestingly proposes her notion of "trans-corporeality" constituted by a "movement across bodies" made of "interchanges and interconnections between various bodily natures" (Alaimo, New Materialisms, Old Humanisms 282). This trans-corporeality is a "movement across different sites, [that] opens up a mobile 'space' [acknowledging] the often unpredictable and unwanted actions of human bodies, non-human creatures, ecological systems, chemical agents, and other actors." (Alaimo, New Materialisms, Old Humanisms 283) Alaimo postulates that her trans-corporeality would necessitate "complex modes of analysis that travel through the entangled territories of material and discursive, natural and cultural, biological and textual" (Alaimo, New Materialisms, Old Humanisms 282).

Alaimo's "trans-corporeality" resonates with Rosi Braidotti's nomadic account of the "becoming-" (becoming-woman, -nomadic, minoritarian, -animal, -posthuman) that aims at decentering the subject from the dualistic grip of oppositional consciousness. Braidotti's becomings take into account embodiment as it is internally differentiated, or in other words, that every being that becomes itself because of some specificities proper to its species, its gender or its race. ${ }^{9}$ Specific embodied positions will be a starting point for Braidotti's nomadic theory since "The body is a surface of intensities and an affective field in interaction with others" (Braidotti, Nomadic Thought 50). Hence, with Alaimo and Braidotti, we see that embodiment is very important for new materialism

\footnotetext{
9 "A nomadic becoming-woman starts from the recognition of the dissymmetry between the sexes and the emphasis on female specificity as the starting point for the process of redefining subjectivity. [...] It moves toward a broadening of the traditional feminist political agenda to include a larger spectrum of options [...] issues that seem to have nothing to do with women at first sight." (Braidotti, Nomadic Thought 41).
} 
because it is where we can analyze our embodied interactions with the material world.

\section{d) Ethics and politics: similar lines of investigations?}

Another crucial commonality between ecofeminism and new materialism is their respective political and ethical goals. Since ecofeminism was contemporary to radical feminism, it has been more explicit in eradicating gender oppression and the oppression of earth others to use Val Plumwood's terms. Ecofeminism appears to lean more toward establishing ethical relationships with natural others, but new materialism is not devoid of suggestions for ethical living either. Throughout her work, Plumwood is adamant to put forward an 'anti-dualist critical ecological feminism' integrative project rejecting logic of domination in conjunction with other liberation struggles (Plumwood, Feminism and the Mastery of Nature 3940). However, unlike new materialists, Plumwood does not want to get rid of ideas of rationality, progress or humanity, but she would rather use them for survival as a species within nature :

If rationality is to have any function for long-term survival, it must [...] find a form which encourages sensitivity to the conditions under which we exist on the earth, one which recognizes and accommodates the denied relationships of dependency and enables us to acknowledge our debt to the sustaining others of the earth. This implies creating a democratic culture beyond dualism, ending colonizing relationships and finding a mutual, ethical basis for enriching coexistence with earth others. (Plumwood, Feminism and the Mastery of Nature 195-196)

In later work, Plumwood also discusses a "progressive naturalism", an interspecies politics recognizing nature as "an active collaborative presence capable of agency and other mindlike qualities" (Plumwood, Nature as Agency 16). Her interspecies politics would reframe relationships to nature in order to grasp the current environmental crisis. ${ }^{10}$

\footnotetext{
10 "The interspecies politics it can make possible could make alliances across species that de-emphasize the importance of generalized and stereotypical species frameworks and differentials and open the door to new kinds of communicative experience-new, that is, for Western culture - which might just begin to frame the world in more sensitive and nuanced terms than we can imagine while wearing the simplifying blinkers of human superiority. These reframings prepare the ground for movement from monological and dualistic types of relationship with nature towards the kinds of structures of relationship we need to develop to begin addressing the environmental crisis at the level of culture. They can open the way for a culture of nature that allows for much more in the way of contextual and negotiated relationships of communication, balanced dialogue, and mutual adjustment between species, starting with our own, in what would be, in the old terms, a liberatory blending or meeting of nature and culture." (Plumwood, Nature as Agency 32).
} 
Here Shiva would agree with Plumwood that we ought to rethink our "ecological categories which [we] think and act [as they] can become the categories of liberation for all, for men and women, for the west and the non-west, and for the human as well as the nonhuman elements of the earth." (Shiva 224). Shiva and Plumwood are political ecofeminists that want to eradicate our categories of oppression, notably by rejecting the link between nature (as passivity) and women (as subrational beings). They both advocate for a liberatory account of ecofeminism.

On the new materialist side, even if epistemology and ontology are at the forefront, ethics and politics are integrated in more or less obvious ways depending on the author. For example, Alaimo and Hekman suggest a 'material ethics' prioritizing embodied ethical practices "situated both temporally and physically [that] may allow for an openness to the needs, the significance, and the liveliness of the more-than-human world" (Alaimo \& Hekman 7-8). These ethical practices would diminish the importance of abstract ethical principles in order to emphasize the importance of material realities where these ethical practices emerge. As they clearly explain: "A material ethics entails, that we can compare the very real material consequences of ethical positions and draw conclusions from those comparisons ... material ethics allows us to shift from ethical principles to ethical practices" (Alaimo \& Hekman 7-8). Hence Alaimo and Hekman's piece presents a new materialist take on ethics that connects new materialist ontology with an ethical way of life. On a different note, Noela Davis, while presenting Vicki Kirby's and Elizabeth Wilson's theories, asserts that new materialism is indeed concerned by politics:

Politics is a material enactment, a relation that worlds the world, and, again, the form of this engagement cannot be prescribed in advance. Nor is politics a separate or limited space of action, but a way of addressing our society. Politics, [Kirby] says, is present to all objects of investigation. There is not a specific conceptual realm of politics and another that is, a priori, not political; nor do we have to dissociate ourselves from one political object to study another. Politics is embedded in life. (Davis 7)

By including politics in all objects of investigation, some new materialists avoid presenting a prescriptive (and potentially totalizing) theory by opening up the political potential of new materialism. While Alaimo and Hekman are more precise in their delimitations of ethical embodied practices that will allow us to be attune to the more-than-human world, other new materialists will remain more vague on what to do to change our practical and ethical attitudes towards the world. Hence ethics and politics are touched by both fields, but in different ways. Sometimes ecofeminism will present a prescriptive account of a progressive interspecies or environmental politics while new materialism will rather 
do upstream work in preparing new ontological and epistemological terrains for afterwards grounding new ethics and new politics. There is a sense in which both fields resonate with one another with respect to their ethics and politics; ecofeminism will put forward specific worldviews that have liberatory goals while new materialisms will rather blur the specificities of some worldviews and question the very ontology of those natural elements constituting them.

\section{e) Common interdisciplinarity}

Finally, another brief commonality between ecofeminism and new materialism is their respective interdisciplinarity. Iris van der Tuin and Rick Dolphijn call new materialism "transversal" because "it intersects academic (neo-)disciplines, ... paradigms ... and the linear spatiotemporalities conventionally assigned to epistemic trends" (Dolphijn and van der Tuin 159). New materialisms indeed unite (although they never pretendto be a united subfield) scholars from quantum physics, biology, sociology, women's studies, art theory, philosophy and so on. Ecofeminism, similarly, brings together thinkers from economy, ecology, biology, geography, history and philosophy. When van der Tuin affirms that new materialism is "itself a distinctive trend" as well as a "tool for opening up theory formation", I think it applies to ecofeminism too (Dolphijn and van der Tuin 2010 159). I am convinced that ecofeminism was not merely a theoretical trend or "only" a political movement. Ecofeminism remains nowadays a subfield of feminist theory that cuts across disciplines and paradigms as well as a motor for ecological and feminist activism. With spiritual ecofeminisms, it is safe to say that, however imperfect and potentially ambiguous, they were rich and complex ontologies and cosmologies. In a sense, some ecofeminists posited new metaphysics and were hinting at new epistemologies, like new materialism does nowadays, but without the same epistemological and scientific precision.

\section{Tensions/Differences}

In Time Travels : Feminism, Nature, Power, Elizabeth Grosz distances her Darwinian project from ecofeminism : "This project is directed primarily at ontological and epistemological claims, while ecofeminism seems largely oriented to ethical, moral, and economic issues" (Grosz 216). Then she proceeds to say that her project does not commit to holism, "the presumption that the interconnectedness of ecological orders forms a systematic whole" unlike ecofeminism, which posits on the whole an interrelated ecosystem. Finally, she says that her project does not give women any special place in relation to nature. Grosz rather believes that 
"the question is to explore the role that different, critically revitalized conceptions of nature may play in our understandings of the becomings open to each sex" (Grosz 216). Obviously, Grosz presents in a nutshell some distinctions to be drawn between ecofeminism and new materialism. Although I believe her last point is a generalization about the complexity of ecofeminism's stance on women, I agree with her claim that ecofeminism is more oriented toward ethical, moral and economic issues than new materialism. Grosz's distinction about her ontological and epistemological vocation will be my starting point to develop more differences between new materialism and ecofeminism.

\section{a) Technology, worldviews and ontologies}

Ecofeminism, related to the ecological movement, often posits an ecological worldview, or a "system" comprising ecosystems, human beings and animals and natural elements as unified and connected, whereas new materialism shuns any kind of totalizing explanation of the world. Moreover, their respective framework is different too: some ecofeminists remain stuck in an anthropocentric framework (Plumwood, Merchant, Warren) while new materialism mainly encompasses antianthropocentric understandings of the world. Related to that, the notion of agency is of crucial importance to distinguish where each field stand: some ecofeminists will grant agency to animals and natural elements, but new materialism goes even beyond that in acknowledging agency to inorganic and inert matter, but also to human-made objects (see Bennett 2010).

As written previously, ecofeminism sometimes partakes in a suspicion against technology, arguing that it further separates us from natural ways of knowing and interacting with nature, a stance that is not without some Heideggerian undertones. Those ecofeminist antitechnology stances view technology as highly gendered; they oppress women and nature by objectifying and exploiting them in similar ways. However, other ecofeminists argue that technology is neutral, that if feminists appropriate and analyze it properly, it could have emancipatory uses.

Prefiguring the new materialist shift, Donna Haraway claimed "I'd rather be a cyborg than a goddess", saying that we ought to integrate technology in our concept of subjectivity, that we cannot get rid of it without getting rid of ourselves. New materialism, along these lines, is interested in the interactions of matter and technology, and especially how they change and impact our notion of agency. New materialism, unlike ecofeminism, has a more open stance on technology as it theorizes the posthuman and the transhuman, going beyond traditional theories of the human subject. The posthuman looks at how intelligent technology and 
humans become increasingly intertwined while the transhuman is "the project of modifying the human species via any kind of emerging science" (Lagrandeur 2014). Braidotti suggests "[t]he boundaries between the categories of the natural and the cultural have been displaced and to a large extent blurred by the effects of scientific and technological advances" (Braidotti, The Posthuman 3). Shifting from humanism to posthumanism requires integrating rather than denigrating technology: it is important to recognize that technology is already part of, and continually affects and changes, our identities and our everyday lives. It is necessary though to be extremely attuned to its potential for oppression within various systematic axes of oppression.

More importantly, posthumanism is ontological. Thus it exceeds the topic of technology; it reconceptualises the subject beyond the human and it theorizes agency outside anthropocentric characteristics of rationality. Stacy Alaimo states that,

Whereas some strands of the nonhuman turn leave the rational human knower intact, others, such as biopolitics, posthumanism, material feminism, and my own conception of 'trans-corporeality' radically reconceive of humanity as animal, biological, materialshaped by evolutionary, environmental, and technological forces as well as by politics and economics. (Alaimo, Sexual Matters 390)

About agency, Samantha Frost notes that the shift advanced by new materialists is one that would move away from a unidirectional account emerging from human beings to a reciprocal account of agency whereas there are agentive effects between the social and the natural. ${ }^{11}$ "They insist that we attend to both the agency of the human or cultural upon the biological or natural and the agency of the natural or biological upon the human or cultural." (Frost 77) Agency is thus 'co-emergent': biology, nature, organisms and sociohistorical contexts all shape one another. Braidotti, when talking about her becomings, argues that we ought to rethink life as bios and shift to life as zoe, the former centering itself around human needs and rights while the latter is a "generative vitality" that "is a transversal force cutting across previously separated domains" (Braidotti, Nomadic Thought 92). How we think about life itself should be decentered from humanity to include all life forces, elements and beings. For instance, the becoming-animal involves expressing their own kind of immanence in the same material world, they exist, depend and interact in zoe like us. They are embodied subjects immersed in their habitats/environments, unlike human beings; the latter have created a

11 "The new materialists aim to shift feminist critical analysis from a framework within which the agency of bodies and material objects is understood largely as an effect of power - a unidirectional account of agency - to a framework within which, for example, culture and biology have reciprocal agentive effects upon one another." (Frost 71). 
distance between them and their environments. Moving from bios to zoe entails a change of position and a change of ontological status of the agent. "The zoe-centered subject is shot through with relational linkages of the symbiotic contaminating/viral kind that interconnect it to a variety of others, starting with the environmental or eco-others." (Braidotti, Nomadic Thought 95)

In a similar fashion, Elizabeth Grosz thinks the natural is the very fabric of the cultural, the material basis that "enables and actively facilitates cultural variation and change, indeed that which ensures that the cultural, including its subjects-agents, are never self-identical, that they differ from themselves and change over time" (Grosz 47). In a Bergsonian vein, Grosz presents the natural as an impetus to diversity; life inserts itself in every corner of matter, in a variety of ways, putting indeterminacy and diversity into material objects and beings. There is a need, for new materialists such as Braidotti and Grosz, to acknowledge "the dynamic interactive processes that constitute organisms, objects, and environments" and hence, alongside other new materialist feminists, "to develop a theoretical vocabulary for talking about the complexity of causation." (Frost 77) Also, reflecting on new materialism, Samantha Frost acutely remarks that

feminists have been more comfortable with denaturalizing nature than with what we might call 'deculturalizing culture' - or admitting that matter or biology might have a form of agency or force that shapes, enhances, conditions, or delimits the agency of culture. ... In their effort to denaturalize nature and deculturalize culture, new materialists push feminists to decenter human intentionality and design in the conceptualization of the relationship between nature and culture. (Frost 76-77)

In other words, new materialism wants to go beyond a 'denaturalization of nature' and a 'deculturalization of culture' in order to take out humanity from definitions of agency.

In tension with new materialism's delineation of agency, Val Plumwood calls for an open revision and renegotiation of the notion of humanity itself. ${ }^{12}$ Although she argues for extending the notion of agency

\footnotetext{
12 "For the notion of humanity itself must come up for revision at the same time, along with the notion of human nature and of what it is to be fully and authentically human, the notion of human virtue. And the question of human relations to nature must come up as part of the re-examination of what it means to be (fully) human. All these concepts must be up for re-examination and renegotiation because the whole notion of humanity itself has been influenced by the masculine/feminine and mind/body dichotomy. And if the model of what it is to be human is basically masculine, then only a shallow feminism could rest content with affirming the 'full humanity' of woman without challenging or examining this model. The human/nature dichotomy then must be up for renegotiation
} 
to animals, she does not give up the humanist account of rationality within the definition of what is the human subject. ${ }^{13}$ Plumwood is critical of the humanist tradition, while still pertaining to it in her own 'anti-dualist critical ecological feminism' way. Indeed, she says:

The oppositional affirmation of and limited focus on human characteristics of humanism has supported both human inequality and human self-enclosure. It has helped us to lose touch with ourselves as beings who are not only cultural but also natural, embedded in the earth and just as dependent on a healthy biosphere as other forms of life.

As such, her account remains anthropocentric, even if she calls for a "progressive naturalism" that would question the traditional humanist focus on the enlightened subject. Interestingly, though, her mention of "embedded in the earth" and "dependent on a healthy biosphere as other life forms" could prefigure the material turn, and specifically the acknowledgement of our reliance on various interactions with the morethan-human, done by new materialists. The way Plumwood presents naturalism makes it obvious that she is committed to "think nature as a positive presence, or as a community of positive presences", hence to rework our conception of nature to see it as a complex entity with its own agency (Plumwood, Nature as Agency 20). She is committed to a 'proto' new materialist understanding of nature, although she sticks with notions of rationality, democracy and progress that remain in the traditional liberal canon.

\section{b) Essentialism and Anti-Essentialism}

Ecofeminism and new materialism differ widely on the question of essentialism. First, Vandana Shiva could be representative of ecofeminist's essentialism as she posits a 'feminine principle' that, within Indian cosmology, "is a 'will-to-become-many', a creative impulse fostering diversity in nature" (Shiva 39). In Staying Alive, this feminine principle is a force where "life in all its forms arise" that is currently destroyed by patriarchal and imperialist development, she asserts, and

along with the masculine/feminine dichotomy." (Plumwood, Feminism and the Mastery of Nature 134).

${ }^{13}$ Plumwood still clings to humanist notions of rationality, democracy and progress : "Despite current temptations to cynicism about the concept of progress, I do not favor any simple abandonment of the concept as inevitably complicit in those dominant narratives; some concepts (like democracy and progress) are just too important to cede to the opposition. Reworking of progress concepts in different terms is part of a reworking of the dominant narrative or reason opposing nature and its leading concepts." (Plumwood, Nature as Agency 5-6). 
"[a]ctivity, productivity, creativity, which were associated with the feminine principle are expropriated as qualities of nature and women, and transformed into the exclusive qualities of man" (Shiva 6). Shiva specifies that the feminine principle is not embodied solely in women, but is a creative force of nature, a principle of activity and creativity present in nature, women and men (Shiva 52). It is "this primordial energy which is the substance of everything, pervading everything" (Shiva 38-40).

As Shiva presents Indian women as the primary farmers holding traditional subsistence farming knowledge, she believes that reclaiming and respecting the feminine principle translate into respecting Indian women's agency. In overlapping women's agency with nature's impetus to diversity, Shiva blurs the distinction between the social and the natural, which can be read as grounding women's agency in nature. By naming the 'will-to-become-many' as feminine, Shiva associates femininity with diversity, hence grounding women's essence in nature. There, she is prey to accusations of essentialism: it is not true that all women embody this diversity principle. Indeed, ecofeminists have argued that to be symbolically and politically associated with nature is to be denied agency, hence if we only reverse the dichotomy and emphasize the connection of women to nature, it does not defuse the essentialism implied in the claim. However, it is important to bear in mind that Shiva's essentialist discourse inscribes itself in the Indian cultural, religious and social context: to dismiss it at the outset is inadvisable.

Hence, due to its sympathetic stance towards nature, ecofeminism did not follow the cultural or linguistic turn of the feminist "denaturalization of nature". In contrast to ecofeminism's attention to essentialism, new materialists seek to challenge essentialism and constructivism. New materialists want to radically challenge and redefine nature as it can "no longer [be] the repository of unchanging truths or determining substances but is itself an active, transforming, signifying, material force" (Alaimo \& Hekman 6). By insisting on the agency of matter, of its interaction with bodies, new materialists thinkers will recast nature as a variety of different material forces and flux that interact with embodied beings in the world. As per Frost's words, new materialist thinkers "deculturalize culture" by advancing new conceptualisations of "nature" without giving it a determinist role. In doing so, 'nature' cannot be used as a justification for grounding essences and identities :

Material feminisms, even as they diverge, insist that the wellgrounded wariness toward domains of essentialism needs to be supplemented by a reconsideration of how substances, bodies, environments, and other material entities are agential, rather than plastic or inert. Moreover, the very ground of essentialism, the biological body, is better thought of as interconnected and 
interactive rather than as some sort of determining core. (Alaimo, Sexual Matters 391)

Moreover, Braidotti asserts it clearly: referents of otherness are not that simple anymore because they do not always coincide with specific embodied characteristics, they are not anymore simple "boundary markers". Braidotti believes that those referents can sometimes be useful to politically organize, but ideally we should move away from them because of the intrinsic risk of essentialism. Subjects are never fixed and determined; rather, a subject, for example 'woman', is always multiple, complex, and constituted by various variables; therefore Braidotti's view are anti-essentialist.

\section{c) Methodologies}

One last tension between ecofeminism and new materialism is their drastically different methodology. A few new materialist thinkers pride themselves in developing a positive or affirmative theory by creating new concepts and by engaging with renowned authors. It is crucial to escape what they call "critique" which leads thinking into dead ends. Critique is trapped in identity politics; it is stuck in a progress narrative asserting that new theorizations are always more relevant than old ones. Such a linear conception should not be embraced, according to Grosz and van der Tuin, rather a rethinking of past concepts while creating new ones should be the way to go. For instance, Grosz writes that critique is not transformative and not necessarily persuasive. Critique is more likely to conceal past theories and their intrinsic values as well as generating unproductive defensive reactions.

Similarly, Rosi Braidotti's "affirmative politics" is a way of doing theory and politics that are not based on recognition political framework (Braidotti, Nomadic Thought 3). While she does not dismiss critical theory per se, she suggests a balance between critique and creation to find social and theoretical alternatives. Braidotti characterizes the linguistic turn as a "negative form of social constructivism" because it has an "oppositional consciousness". She explicitly claims that she is not making "a normative value judgment", but that critique is grounded in negative affects. Negative affects "diminish our capacity to express the high levels of interdependence, the vital reliance on others that is key to a nonunitary vision of the subject and to affirmative ethics" (Braidotti, Nomadic Thought 288) and therefore they do not help create new concepts.

In a way, it is possible to say that ecofeminism still belongs to identity politics in its critique, or revalorization in the case of cultural ecofeminism, of the association between women and nature. Flourishing in various social and natural sciences, ecofeminism has had multiple 
methodologies yet a similar critical perspective: obviously ecofeminists working in geography or in biology never had a similar methodology to ecofeminist philosophers or economists. However, they could share a worldview where gender oppression and environment injustices must be analysed together. For ecofeminism, it is more likely to entail a specific worldview of the natural world in order to begin challenging patriarchal, racist, imperialist and environmental oppression. In a way, ecofeminism would then partake in a progress narrative in tension with new materialism's openness to various future possibilities.

\section{Lingering Issues}

Ecofeminism and new materialism share some objects of study, but they do not approach them in the same manner. I have identified that they connect in their mutual opposition to dualism and dichotomies, and they both have a special interest in embodiment. Also they have a similar goal of positing new ethical practices and new political understandings of the world. As interdisciplinary fields of study, they do not however concord everywhere: ecofeminism, close to ecologist and animal liberation activists, sometimes posits closed ecological systems whereas new materialism challenges that by opening up and complexifying our views of the material world. Moreover, ecofeminism has been more concerned with ethical, political and economical issues while new materialism's work has been so far more directed towards ontological and epistemological inquiry. Also, ecofeminism and new materialism differ on agency: some ecofeminists remain anthropocentric, but most of them acknowledge some form of agency to animals and cannot be called anthropocentric. The question of agency is thus in tension between them: Who is the ecological subject? Can there be a "subject" if we grant agency to inert matter and natural elements? Lastly, they do not approach the constructivismessentialism debate in the same way: while ecofeminism has been somewhat split between its essentialist and constructivist trends, new materialism more boldly goes beyond both constructivism and essentialism.

Another commonality lingers in this paper: they share similar blind spots. Both ecofeminismand new materialisms have been challenged due to their controversial natures as well as due to the scope of their research. How can they be feminist subfields of research if they do not investigate on gender specifically? A strong criticism against new materialism is that we cannot get away with humanity just yet when there are so many problems remaining among us, such as racism for instance. A certain color-blind bias among new materialists shows a lack of recognition of agency and subjectivity to racialized populations. How can we look at the 
posthuman when we do not recognize some - mostly racialized populations within the definition of humanity itself?

Ecofeminism has been criticized for cultural appropriation of Indigenous and Native spiritualities, for being Western-centric and colorblind. Yet, there is a revival of interest for spiritual ecofeminism amongst Millenial feminists ("Goddess" and "Wiccan" spiritualities) that is similar to early cultural ecofeminism, but maybe with a greater flexibility around issues of gender identities. Also, ecofeminist activism is interconnected more than ever before with struggles against speciesm, racism, colonialism: women have taken their place within ecological movements with a broad intersectional analysis. Currently, Native Women lead the Canadian Idle No More movement across the country for the protection of unceded Native lands and against pollution of the Earth and water. Even if this particular group does not self-identify as ecofeminist, they do mobilize women around crucial environmental and ontological issues in making explicit the link between land and embodiment and how they have been structured by the colonial and patriarchal state. I strongly believe there are inspiring coalitions to construct, theoretically and politically, between ecofeminists and new materialists. New materialist dynamic work has the resources to open up some ecofeminists' closed worldviews and in return ecofeminism's ethical emphasis on oppression can ground ontological claims to political ones. 


\section{Work Cited}

ADAMS, Carol J. The Sexual Politics of Meat: A feminist vegetarian critical theory, New York: Continuum, 1990.

AGARWAL, Bina. "Challenge for Ecofeminism: Gender, Greening, and Community Forestry in India", Women \& Environment International Magazine 52/53, Fall 2001.

AHMED, Sara. "Open Forum: Imaginary Prohibitions: Some Preliminary Remarks on the Founding Gestures of New Materialism", European Journal of Women's Studies 15, no. 1, 23-39, 2008.

ALAIMO, Stacy. "Sexual Matters: Darwinian Feminisms and the Nonhuman Turn", J19: The Journal of Nineteenth-Century Americanists 1, no. 2, Fall 2013, pp. 390-396

—. "New Materialisms, Old Humanisms, or, Following the Submersible", NORA - Nordic Journal of Feminist and Gender Research 19, no. 4, 280-284, 2011.

—. "Ecofeminism without Nature?", International Feminist Journal of Politics 10, no. 3, 299-304, 2008.

ALAIMO, Stacy and Hekman, Susan. Material Feminisms, Bloomington: Indiana University Press: 2008.

BENNETT, Jane. Vibrant Matter : a Political Ecology of Things, Durham and London: Duke University Press, 2010.

BRAIDOTTI, Rosi. Nomadic Theory : The Portable Rosi Braidotti, New York: Columbia University Press, 2011.

—. The Posthuman, Cambridge: Polity Press, 2013.

COOLE, Diana and Frost, Samantha. New Materialisms :Ontology, Agency, Politics, Durham and London: Duke University Press, 2010.

DALY, Mary. Gyn/Ecology: The Metaethics of Radical Feminism, Boston: Beacon Press, 1978.

DAVIS, Noela. 'New Materialism and Feminism's Anti-Biologism: A Response to Sara Ahmed" European Journal of Women's Studies 16 , no. 67, 67-80, 2009. 
—. "Politics Materialized : Rethinking the Materiality of Feminist Political Action through Epigenetics", Women: A Cultural Review 25, no. 1, 62-77, 2014.

DIAMOND, Irene and Orenstein, Gloria Feman. Reweaving the World : The Emergence of Ecofeminism, San Francisco: Sierra Club Books, 1990.

D'EAUBONNE, Françoise. Le féminisme ou la mort, Paris: Éditions P. Horay, 1974.

DOLPHIJN, Rick and van der Tuin, Iris. New Materialism : Interviews and Cartographies, Ann Arbor: Open Humanities Press, 2012.

FROST, Samantha. "The Implications of the New Materialisms for Feminist Epistemology", H.E. Grasswick (ed.), Feminist Epistemology and Philosophy of Science: Power in Knowledge, New York: Springer, 2011.

GROSZ, Elizabeth. Time Travels : Feminism, Nature, Power, Durham: Duke University Press, 2005.

GRUEN, Lori. Ethics and Animals: An introduction, Cambridge: Cambridge Univeristy Press, 2011.

HARTSOCK, Nancy C. M. "The Feminist Standpoint: Developing the Ground for a Specifically Feminist Historical Materialism" in Discovering Reality, ed. By Sandra Harding and Merrill B. Hintikka, D. Boston : Reidel Publishing Company, 1983.

HINTON, Peta and van der Tuin, Iris. "Preface". Women: A Cultural Review, Special issue 'Feminist Matters: The Politics of New Materialism', 25, no. 1, 1-8, 2014.

LAGRANDEUR, Kevin. Institute for Ethics and Emerging Technologies. "What is the difference between Posthumanism and Transhumanism". Web. July $28^{\text {th }} 2014$.

MAATHAI, Wagari. Pour l'amour des arbres, Paris: Éditions L'Archipel, 2005.

MERCHANT, Carolyn. The Death of Nature, San Francisco: Harper and Row Publishers, 1980.

MIES, Maria and Shiva, Vandana. Écoféminisme, New Jersey: Zed Books, 1993. 
PLUMWOOD, Val. "Nature as Agency and the Prospects for a Progressive Naturalism", Capitalism, Nature, Socialism 12, no. 4, 3-32, 2001.

—. "Ecofeminism: An Overview and Discussion of Positions and Arguments", Australasian Journal of Philosophy 64, suppl. 1, 120138, 1986.

—. Feminism and the Mastery of Nature, New York: Routledge, 1993.

SHIVA, Vandana, Staying Alive: Women, Ecology and Survival in India, New Delhi: Gayatri Offset Press, 1988.

STARHAWK, The Spiral Dance : A Rebirth of the Ancient Religion of the Great Goddess, San Francisco: Harper \& Row, 1989.

TWINE, Richard. "Ma(r)king Essence: Ecofeminism and Embodiment", Ethics and the Environment 6, no.2, 31-58, 2001.

VAN DER TUIN, Iris. “Deflationary Logic: Response to Sara Ahmed's 'Imaginary Prohibitions: Some Preliminary Remarks on the Founding Gestures of the "New Materialism", European Journal of Women's Studies 15, no. 4, 411-416, 2008. 